\title{
Vikings Table: An Innovative Social Venture
}

\author{
Catherine Loes \\ Belmont University \\ Dana Shaw \\ Belmont University
}

The Minnesota Vikings National Football League team has partnered with a number of food insecurity nonprofits since the 1960s. Recently the organization has taken an innovative approach to bridge the gap for low-income children in the Twin Cities area who may go without meals, especially during the summer months. The Vikings, in conjunction with Second Harvest Food Bank and other individual and corporate donors, have built a custom-made food truck. The truck, completely decorated with the team's name and logo will be present at all Vikings events operating as a normal food truck selling items to patrons of those events. The innovative concept behind the truck is its second purpose-feeding those in need. The proceeds from the sale of food during the Vikings events will fund the meals program.

Keywords: philanthropy, social entrepreneurship, sport management, corporate social responsibility

\section{Learning Outcomes}

In completing this assignment, students should be able to:

1. Evaluate the sustainability of the Vikings table.

2. Argue the rationale for organizations to engage in their community.

3. Examine the rise of socially responsible initiatives by sport organizations

4. Compare professional sports organization's community contributions from charity to social entrepreneurship.

5. Compare and contrast different approaches to corporate social responsibility.

\section{Application}

The case is most appropriate for undergraduate courses in sport management, social entrepreneurship, and business management.

\section{INTRODUCTION}

\section{Corporate Social Responsibility (CSR) in Sports}

Nearly every professional sports team has established charitable foundations over the past fifteen years indicating a heightened awareness of the social responsibility felt by owners and players. (Babiak, 2009). While CSR has long been discussed and researched for business organizations, recent emphasis is being placed on sport organizations due to a considerable number of leagues and teams creating 
philanthropic- related activities. Bradish and Cronin (2009) reflect on the major contributions of CSR research and conclude that "CSR should be regarded as one of the most important components of contemporary sport management theory and practice" (p. 696).

"Daniel Borochoff, president of the American Institute of Philanthropy, said America's celebrityobsessed culture has fueled a trend toward fund-raisers built around athletes. Charities like such events because they attract wide audiences and broad media coverage, and association with popular public figures can raise their profiles. Athletes with solid reputations also lend credibility to charities, enhancing organizations' images through their association with them" (Blount, 1999, p. 1c).

\section{Social Enterprise}

Social Enterprises are different from profit-seeking enterprises in that, they seek to provide social, economic, and environmental benefits to their stakeholders. Yet, in order for social enterprises to be sustainable, they must also successfully overcome the same operational challenges of forecasting, inventory management, and capacity that for-profit organizations face. Much of the literature questions whether a social enterprise that focuses on providing a social good can be sustainable in a for-profit economy.

The definition of social enterprise/entrepreneurs has several different perspectives and remains lacking one significant definition. Alvord, Brown, \& Letts (2004) suggest a social entrepreneur creates innovative solutions to social problems and creates ideas and resource for sustainable transformations (p. 262). Hartigan (2006) suggests the work of social entrepreneurs is geared toward progressive social transformation - a business model aimed to create change. Although profits are generated, the main goal is to reach people more effectively not to generate financial returns for shareholders. Revenues generated over the cost of production are reinvested in the social venture to fund expansion. (p. 45). Hockerst (2006) suggests social ventures are a hybrid that crosses both for-profit and social mission-driven public and non- profit organizations-not fitting perfectly in either category (p. 145). Korosec and Berman (2006) address both the entrepreneur and the entrepreneurial organization. Entrepreneurs are those individuals or organizations that initiate solutions to address social issues in their communities by developing new programs and solutions to specific problems of special populations in their communities (pp 448-449). Sharir and Lerner (2006) address the issue of resources and that social entrepreneurs create sustained social value without being constrained by limited resources (p. 3).

Reise (1999) and Thompson (2002) suggest social entrepreneurship occurs when business knowledge and market-driven concepts are applied to the nonprofit section to solve social issues. Thompson and Doherty (2006) and Yunus (2008) suggest social entrepreneurship can be defined as any business solution seeking to solve a social good either through nonprofit or for-profit initiatives. We use the definition of social entrepreneurship developed by Austin, Stevenson, Wei-Skillern (2006) for its applicability across sectors. They suggest social entrepreneurship as an innovative, social value-creating activity that can occur within or across the nonprofit, business, or government sectors (p.2).

"We suggest that social entrepreneurs are more likely to pay attention to external resources and develop creative mechanisms to circumvent environmental barriers: unlike conventional entrepreneurs, social entrepreneurs rarely allow the external environment to determine whether or not they will launch an enterprise. In line with this thinking, we suggest that there are fruitful opportunities for the research focused on how social entrepreneurs leverage three key bundles of resources-relational, cultural, and institutional (Dancin, Dancin, Matear 2010, p. 48).

A social enterprise's lack of funding may force it to be more creative and resourceful in its day-to-day operations. Additionally, these organizations may rely on volunteers or part-time transient labor. Austin, Stevenson and Wei-Skillern (2006) state that "while the human and financial resources required for success have similarities across commercial and social entrepreneurship, social entrepreneurs are often faced with more constraints: limited access to the best talent; fewer financial institutions, instruments, and resources; and scarce unrestricted funding and inherent strategic rigidities, which hinder their ability to mobilize and deploy resources to achieve the organization's ambitious goals" ( p.12). 


\section{History and Mission}

Running back, Dalvin Cook, hangs out the window of the Viking Table Food Truck serving youth from the Southside Village Boys and Girls Club. He is one of several Minnesota Viking players who have served in the new initiative to help address the problem of food insecurity in the local community. The initiative launched in June of 2019 is already having success in generating funds and redistributing proceeds to those in need as 45 underserved communities have already benefited with healthy meals and nutrition education.

The Viking's organizations have been an integral part of the St. Paul and Minneapolis (Twin Cities) community since its creation in 1960. Minnesota was granted a franchise to build a professional football team just prior to the American Football League (AFL) and National Football League (NFL) merge into what is now widely known as the NFL. The Vikings Children's Fund created in 1978 gave over 11 million dollars to children and families in Minnesota and the Upper Midwest. Some of the charities included a focus on children's healthcare, education, and food insecurity (Anderson, 2013).

In 2017 the Vikings replaced the Viking's Children's Fund. The Vikings Foundation is a public charity dedicated to advancing the well-being of youth through engaging health and education initiatives (Vikings.com). The newly formed foundation will focus on childhood hunger, fitness, and education. For the first time in decades, the life expectancy has declined and in Minnesota has one of the largest achievement gaps in the country as evidenced through test scores and graduation rates (Startribuine June $30,2010)$.

In 2018 the Vikings launched an innovative social initiative partnering with Second HarvestVikings Table. Vikings Table is a multi-purpose, costume-built food truck that will serve meals to lowincome inner-city children. Vikings Executive Director of Social Impact Brett Taber says "Vikings Table is a new and important program of the Vikings Foundation's greater mission, which has always been to advance the well-being of youth through engaging health and education initiatives. Approximately 250,000 children in the Minneapolis-St. Paul area is missing meals during the summer months. We're excited to partner with other non-profit organizations and leverage the power of the Vikings brand to bring people together in the fight against hunger" (Vikings, 2019). The Vikings Table is an innovative way to use the Vikings brand to address a major social issue and allows young fans to see professional athletes like Dalvin Cook, known as "The Chef" giving back to the community.

\section{REFERENCES}

Aldrich, H., \& Martinez, M. (2001). Many are called, but few are chosen: An evolutionary perspective for the study of entrepreneurship (Discussion Paper). Chapel Hill, NC: University of North Carolina.

Anderson, J. (2013, May 14). Vikings make spirited contributions to the community. Star Tribune Metro Edition News section, pp. 1.

Austin, J., Stevenson, H., \& Wei-Skillern, J. (2006, January). Social and commercial entrepreneurship: Same, different, or both? Entrepreneurship Theory and Practice.

Babiak, K., \& Wolfe, R. (2009). Determinants of Corporate Social Responsibility in Professional Sport: Internal and External Factors. Journal of Sport Management, 23, 717-742.

Blount, R. (1999, June 25). It's all about giving and getting: Athletes make good fund-raisers, and when they get involved, they usually end up feeling pretty good, too. Star Tribune, Metro Edition. Section Sports, pp.1C.

Bradish, C., \& Cronin, J.J. (2009). Corporate Social Responsibility in Sport. Journal of Sport Management, 23, 691-697.

Dancin, P., Dancin, T., \& Matear, M. (2010, August). Social Entrepreneurship: Why We Don't Need a New Theory and How We Move Forward. Academy of Management Perspectives, 24(3), 37-57.

Hartigan, P. (2006). It's about people, not profits. Business Strategy Review, 17(4), 42-45.

Hockerts, K. (2006). Entrepreneurial opportunity in social purpose business ventures. In J. Mair, J. Robinson, \& K. Hockerts (Eds.), Social entrepreneurship. Basingstoke. UK: Palgrave Macmillan. 
Korosec, R.L., \& Berman, E.M. (2006). Municipal support for social entrepreneurship. Public Administration Review, 66(3), 448-462.

Minnesota Viking Foundation. (2019, June 14). Vikings Table” food truck build by Winnebago Industries. Marketwatch.com. Retrieved from https://www.marketwatch.com/press-release/minnesotavikings-foundation-vikings-table-food-truck-built-by-winnebago-industries-2019-06-14-618300

Nicholls, A., \& Cho., A. (2006). Social Entrepreneurship: The structuration of a field. In A. Nicholls (Ed.), Social Entrepreneurship: New Models of Sustainable Social Change. Oxford University Press, Oxford.

Reis, T. (1999). Unleashing the new resources and entrepreneurship for the common good: A scan, synthesis and scenario for action. Battle Creek, MI: W.K. Kellogg Foundation.

Sharir, M., \& Lerner, M. (2006). Gauging the success of social ventures initiated by individual social entrepreneurs. Management Decision, 38, 328-338.

Stevenson, H. (1985). The heart of entrepreneurship. Harvard Business Review, 63, 85-94.

Sud, M., VanSandt, C., \& Baugous, A. (2008). Social entrepreneurship: The role of institutions. Journal of Business Ethics, (85), 201-206.

Thompson, J. (2002). The world of the social entrepreneur. International Journal of Public Sector Management, 15(5), 412-431.

Thompson, J., \& Doherty, B. (2006). The diverse world of social enterprise: A collection of social enterprise stories. International Journal of Social Economics, 33(5/6), 399 -410.

Yunus, M. (2008). Creating a world without poverty: Social business and the future of capitalism. New York: Public Affairs Books. Retrieved from www.Vikings.com 


\section{TEACHING NOTE}

\section{Vikings Table: An Innovative Social Venture}

\section{Case Overview}

The Minnesota Vikings National Football League team has partnered with a number of food insecurity nonprofits since the 1960s. Recently the organization has taken an innovative approach to bridge the gap for low-income children in the Twin Cities area who may go without meals, especially during the summer months. The Vikings, in conjunction with Second Harvest Food Bank and other individual and corporate donors, have built a custom-made food truck. The truck, completely decorated with the team's name and logo will be present at all Vikings events operating as a normal food truck selling items to patrons of those events. The innovative concept behind the truck is its second purposefeeding those in need. The proceeds from the sale of food during the Vikings events will fund the meals program.

\section{Application}

The case is most appropriate for undergraduate courses in sports management, social entrepreneurship, management, etc.

\section{Research Methods}

This is a critical incident case and all data were collected from widely accessible sources.

\section{Learning Outcomes}

1. Evaluate the sustainability of the Vikings table.

2. Argue the rationale for organizations to engage in their community.

3. Examine the rise of socially responsible initiatives by sport organizations.

4. Compare professional sports organization's community contributions from charity to social entrepreneurship.

5. Compare and contrast different approaches to corporate social responsibility.

\section{Discussion Questions}

1. What does sustainability mean for Vikings Table? (LO 1)

2. Distinguish between non-profit services and corporations that engage with its communities to help solve a social good. (LO 2)

3. How can sport organizations ensure continuity and provide stability to the community when sports are a volatile profession? (LO 3)

4. Give examples of hypothetical situations in which philanthropy would not be a positive action of CSR. (LO 4)

5. Classify the different theories of CSR the Minnesota Vikings may consider to explain its creation of Vikings Table. (LO 5)

6. Describe the type of resources the Minnesota Vikings leveraged to launch and sustain the Vikings Table initiative. (LO 5)

\section{Answers to Discussion Questions}

\section{What does sustainability mean for Vikings Table? (LO 1)}

Researchers at the University of Toronto explored social enterprise failure rates and identified both external and internal factors that led to these failures. The external factors include limited access to funding and governmental legal support while the internal factors include funding gaps between revenue 
and grants, lack of business skills and strategic focus, and tension between the organization's social mission and drive for profitability (Rykaszewski and Shen, 2013). Scott and Teasdale suggest social enterprises fail for many of the reasons listed and in a more holistic description "many organizations termed 'social enterprises' face an inherent tension between their two objectives, in that their social and enterprise goals might not be reconcilable" $(2012$, p. 15).

\section{Distinguish between non-profit services and the alignment with corporations. (LO 2)}

Nicholls and Cho (2006) argue that the ultimate goal of a social enterprise is to change an existing faltering system. The change should remove or eliminate barriers for either the organization or more importantly its clients. "Because of these obstacles are the products of a wide range of social institutions, all of those institutions must be involved in their destruction" (Sud, VanSandt, Baugous, 2008, p. 211). Drucker (1998) offers further insight into the relationship between nonprofits and for-profit entities. He suggests corporations could learn lessons from nonprofits the first is to align its scarce resources to achieve its mission through simple, direct actions. For-profit organizations often steer off course looking for new markets or towards new ideas, a luxury most nonprofits lack. This focus on mission provides clear guidance for the employees, its customers, and all stakeholders. The second suggestion Drucker offers is for corporations to consider the power of valuable and meaningful work for employees. He suggests one reason many corporate employees volunteer is their desire to be involved in meaningful work. This sediment is echoed by Dan Pink (2011) who suggests meaning in one's work can be one of the most powerful motivating forces for employees.

\section{How can sport organizations ensure continuity and provide stability to the community due to the volatile nature of the industry? (LO 3)}

There are many factors that may affect a sport organization and its ability to invest into the community. A decrease in revenue or the threat of moving to another city can affect a community if there is reliance on the organization for specific needs such as food. Although most teams have charities and foundations, the support of the league office and other non-profit organizations can help to ensure continuousness of support. League initiatives help to bring continuity as seen by the following programs:

In 2005 the FIFA Congress decided to add a new dimension to the governing body's mission "to build a better future" by taking a massive step towards fulfilling the United Nations' Millennium Development Goals, namely the allocating of at least $0.7 \%$ of all the revenue it generates to the program's social responsibility initiatives The FIFA Foundation serves in numerous ways throughout the world (FIFA, 2019).

NBA Cares is the league's global social responsibility program that builds on the NBA's mission of addressing important social issues in the U.S. and around the world. NBA Cares works with internationally recognized youth-serving programs that support education, youth, and family development, and health-related causes, including Special Olympics, Boys \& Girls Clubs of America, UNICEF, the Make-A-Wish Foundation, Share Our Strength and GLSEN. NBA Cares programs and participants have provided more than 5 million hours of hands-on service, created more than 1,300 places where kids and families can live, learn or play and engaged more than 51 million youth in basketball programs in communities around the world. Internationally, NBA Cares has created more than 323 places where kids and families can live, learn, or play in 40 countries (NBA cares, 2019).

Football and community are the twin pillars of the NFL. Whether nationally at the league level, locally at the team level, or individually through the volunteerism and philanthropy of owners, players, coaches and club personnel, there exists a powerful NFL-wide commitment to giving back. The NFL embraces its role in unifying our communities, addressing key social issues and serving as a force for positive change (NFL, 2019). 


\section{Give examples of hypothetical situations in which philanthropy would not be a positive action of CSR. (LO 3)}

A 2008 McKinsey Global Survey reports company leaders were highly uncertain the philanthropic efforts undertaken by the organization resulted in tangible results either for the social cause or the organization. These sediments can further be supported by Friedman's famous 1970 article in the New York Times. He suggests corporations are entities and are not able to be socially responsible only people can be. He continues by explaining that if organizations work to make a profit, pay its employees well, follow the rules and laws of the land then allow employees as private citizens to engage in community or social issues.

\section{Classify the different theories of CSR the Minnesota Vikings may consider explaining its creation of Vikings Table. (LO 4)}

\section{Triple Bottom Line}

Triple bottom line (TBL), originally coined by John Elkington in 1994 "focuses corporations not just on the economic value they add, but also the environmental and social value that they add - destroy" (Elkington, 2004, p. 3). Triple bottom line is calculated in economic, social, and environmental indicators in a sustainable way. Sustainable can be understood as the maintenance of long-term balance. Economic indicators are driven in prolonged stable long-term stability over short-term more volatile gains. Social sustainability balances the peoples' lives and the way they live. An example may be the involvement of fair-trade involvement. And environmental balance which may be seen through the acknowledgment and actions towards reducing waste and environmental impact.

\section{Stakeholder Theory}

Stakeholder theory is often seen as the mirror image of corporate social responsibility and has been defined "as anyone (person, entity) whose lives are touched by a corporation or hold a right and obligation to participate in directing it" (Creative Commons). In Freeman's 1984 landmark work Strategic Management: A Stakeholder Approach he suggests corporations have relationships with several constituent groups that are affected by its decisions. Instead of starting with business and looking out into the world to see what ethical obligations are there, stakeholder theory starts in the world and looks inward. It lists and describes those individuals and groups affected by the company's actions and asks, "What are their legitimate claims on the business?" "What rights do they have with respect to the company's actions?" and "What kind of responsibilities and obligations can they justifiably impose on a particular business?"

Some argue universal stakeholders may include shareholders, workers, customers, suppliers, and the community. What can be argued is that stakeholder theory obligates corporate managers and executives to appeal to all sides and balance everyone's interests and welfare in the name of maximizing benefits across the spectrum of those whose lives are touched by the

business. Donaldson and Preston (1995) suggest that stakeholder theory is a managerial in nature and encompasses attitudes, practices, and policies that when combines offer a clear picture of stakeholder philosophy.

\section{The Four Responsibilities}

As one of the first cohesive models of CSR, this hierarchical approach provides a lexicon for evaluation of organizational resources. The responsibilities are defined as economic, legal, ethical, and discretionary. [Review and add from Carroll, 2016]. This model offers "both a descriptive theory of how managers may make tradeoffs among competing demands for organizational resources and a prescriptive model of the circumstances where such tradeoffs may be appropriate (e.g. firms struggling to make profits should not focus on discretionary CSR activities)," (Godfrey, 2009, p.704) 


\section{Describe the type of external resources the Minnesota Vikings leveraged to launch and sustain the Vikings Table initiative. (LO 4)}

Dancin, Dancin, and Matear (2010) suggest "social entrepreneurs are more like to pay attention to external resources and develop creative mechanisms to circumvent environmental barriers: Unlike conventional entrepreneurs, social entrepreneurs rarely allow the external environment to determine whether or not they will launch an enterprise" ( $\mathrm{p} 48$ ).

Three types of external resources may be considered when evaluating organizations and their capabilities in a social context. Often social ventures use these resources collaboratively instead of exclusively as may be seen in a conventional for-profit entity.

\section{Relational}

Relational is the necessary social capital, creative interactions, and formal and informal networks the organization has access to build on and communicate messages. (Aldrich \& Martinez, 200, Manev, Gyoshev, and Manoliva 2005, Robinson, 2006).

\section{Cultural Resources}

Knowing the social norms, values, behaviors, attitudes, and beliefs of communities is a critical resource for social entrepreneurs. "Knowing what is and isn't permitted - or expected or considered legitimate-by social and cultural standards is key to developing successful social entrepreneurial strategies and operational plans" (Dancin, Dancin, Maeter, 2010, p. 49).

\section{Institutional Resources}

Possibly the most important of the three resources are creating new resources rather than relying on existing ones by leveraging the organizations current political, legal and institutional infrastructure. Understanding the strength and weaknesses in institutional frameworks may provide an advantage to achieve sustainability.

\section{REFERENCES}

Alvord, S.K, Brown, D.L., \& Letts, C.W. (2004). Social entrepreneurship and societal transformation: An exploratory study. Journal of Applied Behavioural Science, 40, 260- 282.

Carroll, A. (2016). Carroll's Pyramid of CSR: Taking Another Look. International Journal of Corporate Social Responsibility. DOI 10.1186/s40991-016-0004-6

Creative Commons. (n.d.). "Three Theories of Corporate Social Responsibility", section 13.2 from the book Business Ethics (v. 1.0). Retrieved from https://2012books.lardbucket.org/books/businessethics/s17-02-three-theories-of-corporate-so.html

Dancin, P., Dancin., T., \& Matear, M. (2010, August). Social entrepreneurship: Why we don't need a new theory and how we move forward from here. Academy of Management Perspectives, pp. 37-57.

Donaldson, T., \& Preston, L. (1995). The stakeholder theory of the corporation: Concepts, evidence, and implications. Academy of Management Review, 20(1), 65-91.

Drucker, P. (1989, July-August). What business can learn from nonprofits. Harvard Business Review.

Elkington, J. (2004). Enter the triple bottom line. In the Triple Bottom Line: Does it all add up (1st edition). London. Routledge.

FIFA. (2008). Men's Youth Olympic. Retrieved from https://www.fifa.com/mensyoutholympic/news/y=2008/m=6/news=social-responsibility795910.html

Freeman, R.E. (1984). Strategic management: A stakeholder approach. Englewood Cliffs. NJ: PrenticeHall.

Friedman, M. (1970, September 13). The Social Responsibility of Business is to Increase its Profits. New York Times Magazine. 
Godfrey, P. (2009). Corporate Social Responsibility in Sport: An Overview and Key Issues. Journal of Sport Management, 23, 698-716.

Hartigan, P. (2006). It's about people, not profits. Business Strategy Review, 17(4), 42-45.

Hockert's, K. (2006). Entrepreneurial opportunity in social purpose business ventures. In J. Mair, J. Robinson, J., \& K. Hockerts (Eds.), Social entrepreneurship. Basingstoke. UK: Palgrave Macmillan.

Manev, I., Gyoshev, B., \& Manolova, T. (2005). The role of human and social capital and entrepreneurial orientation for small business performance in a transitional economy. International Journal of Entrepreneurship and Innovation Management, 5(3/4), 298-318.

NBAcares. (2019). Mission. Retrieved from https://cares.nba.com/mission/

NFL. (2019). Learn More about NFL in the Community. Retrieved from https://community.nfl.com/

Nicholls, A., \& Cho, A. (2006). Social Entrepreneurship: The structuration of a field. In A Nicholls (Ed.), Social Entrepreneurship: New Models of Sustainable Social Change. Oxford University Press, Oxford).

Pink, D. (2011). Drive: The surprising truth about what motivates us. Riverhead Books.

Robinson, J. (2006). Navigating social and institutional barriers to markets: How social entrepreneurs identify and evaluate opportunities. In. J. Mair, J. Robinson, \& K. Hockerts (Eds), Social entrepreneurship. Basingstoke, UK: Palgrave Macmillan.

Rykaszewski, M., \& Shen, Y. (2013, Spring). Failure in social enterprises. See Change Magazine.

Scott, D., \& Teasdale, S. (2012). Whose failure? Learning from the financial collapse of a social enterprise in "Steeltown". Voluntary Sector Review. The Policy Press, 3(2), 139-55.

Sud, M., VanSandt, C., \& Baugous, A. (2008). Social entrepreneurship: The role of institutions. Journal of Business Ethics, 85, 201-206.

Thompson, J., \& Doherty, B. (2006). The diverse world of social enterprise: A collection of social enterprise stories. International Journal of Social Economics, 33(5/6), 399 -410.

Yunus, M. (2008). Creating a world without poverty: Social business and the future of capitalism. New York: Public Affairs Books. 